\title{
Chapter 13 \\ The Humanitarian Atom: The Role \\ of Nuclear Power in Addressing \\ the United Nations Sustainable \\ Development Goals
}

\author{
Sama Bilbao y Leòn and John C. H. Lindberg
}

\section{Contents}

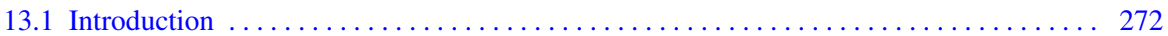

13.2 The Centrality of (Clean) Energy to Sustainable Development and the Role of Nuclear

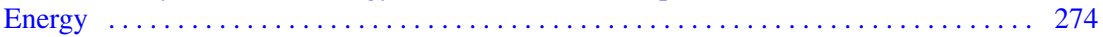

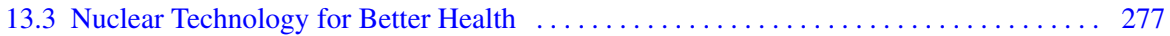

13.3.1 Cleaner Air with Nuclear Power ................................. 277

13.3.2 Combating Cancer and Other Diseases ......................... 279

13.3.3 Providing Fresh and Clean Water with Nuclear Technology .............. 280

13.3.4 Combating Hunger with Nuclear Technology ...................... 282

13.4 Protecting the Environment with Nuclear Energy $\ldots \ldots \ldots \ldots \ldots \ldots \ldots \ldots \ldots \ldots \ldots \ldots$

13.4.1 Habitat Destruction and Biodiversity Loss $\ldots \ldots \ldots \ldots \ldots \ldots \ldots \ldots \ldots$

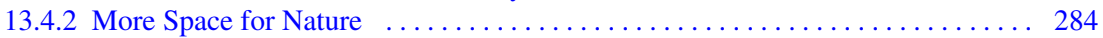

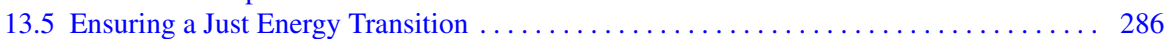

13.5.1 Nuclear Energy Strengthening Energy Independence . . . . . . . . . . . . . 287

13.5.2 Minimizing the Legacy for Future Generations $\ldots \ldots \ldots \ldots \ldots \ldots \ldots . \ldots 288$

13.5.3 An Affordable and Value-Creating Transition with Nuclear Energy ........ 289

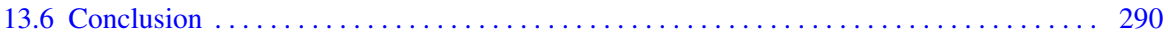

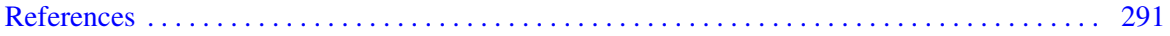

\begin{abstract}
After decades of mostly rhetoric on climate change, robust and urgent actions must be taken to avoid its worst effects. However, the energy transition discourse reflects an anti-humanitarian philosophy that will undermine any serious efforts of achieving decarbonisation, as well as merely entrenching already-existing global inequalities. The potential of nuclear power for radically reducing greenhouse gas emissions has been well-explored. However, to date, few attempts have been made to fully discern the broader positive impacts nuclear technology can have on
\end{abstract}

S. B. y Leòn $(\varangle)$ · J. C. H. Lindberg

World Nuclear Association, London, UK

e-mail: Official.Mail@iaea.org

J. C. H. Lindberg

King's College London, London, UK

Imperial College London, London, UK 
achieving sustainable and equitable development. Nuclear science and technology have broad applications and should be placed at the centre of policies aimed at combatting energy poverty, reducing air pollution, providing clean water, addressing food insecurity, or fulfilling any other of the United Nations' 17 SDGs. This chapter explores the centrality of energy in ensuring sustainable development, a just energy transition, and the importance of nuclear energy, which goes far beyond simply delivering low-carbon electricity.

Keywords Climate change $\cdot$ Sustainable development goals $\cdot$ Nuclear energy Low-carbon energy $\cdot$ Nuclear technology $\cdot$ Cancer $\cdot$ Clean water $\cdot$ Hunger $\cdot$ Clean air $\cdot$ Biodiversity $\cdot$ Environment $\cdot$ Net zero $\cdot$ Energy transition

\subsection{Introduction}

The coronavirus pandemic has added to the many challenges that humanity faces, ranging from the effects of climate change and air pollution to chronic malnutrition, water scarcity, forced displacement and growing inequality. Even before the pandemic, a major step change was required to meet the United Nations (UN) Sustainable Development Goals (SDGs) by the 2030 deadline. ${ }^{1}$ Whilst the pandemic has highlighted the many global inequalities that still exist, the immense progress in human development that has taken place since the end of the Second World War must not be diminished. Standards of living across the world have increased: in $1950,55 \%$ of the global population lived in extreme poverty, with $72 \%$ living in poverty, ${ }^{2}$ while in 2017 the same figures were $9.3 \%$ and $40 \%$, respectively. ${ }^{3}$ In 1950 , $24.7 \%$ of all children died before the age of five, while in 2018 , the same figure was $3.9 \% .{ }^{4}$ In less than 50 years, the number of people suffering from starvation or undernourishment has decreased by $17 \%,{ }^{5}$ while in less than 20 years, the amount of people with access to electricity has increased, from $72.8 \%$ in 2000 to $90 \%$ in $2019 .{ }^{6}$

Most of this astounding progress in human living standards has been powered by fossil fuels. For the next chapter of human progress, the challenge is to find ways of safeguarding the progress already made, while ensuring that humanity's use of resources and the environment is sustainable. Human activities have had a considerable impact on the Earth system and urgent actions are required to avoid further

\footnotetext{
${ }^{1}$ UN 2021.

${ }^{2}$ Bourguignon and Morrisson 2002.

${ }^{3}$ https://data.worldbank.org/topic/poverty. Accessed 1 July 2021; https://www.worldbank.org/en/ news/press-release/2020/10/07/covid-19-to-add-as-many-as-150-million-extreme-poor-by-2021. Accessed 1 July 2021.

${ }^{4}$ https://www.gapminder.org/data/documentation/gd005/. Accessed 1 July 2021.

${ }^{5}$ Rosling et al. 2018.

${ }^{6} \mathrm{https} / / /$ www.iea.org/reports/sdg7-data-and-projections/access-to-electricity. Accessed 1 June 2021.
} 
destabilization of the planet's habitability. ${ }^{7}$ A major driver is the unsustainability of the current developmental trajectory, with anthropogenic climate change being one of the symptomatic challenges, which the United Nations has called "the defining issue of our time". ${ }^{8}$ In order to keep global warming below $1.5^{\circ} \mathrm{C}$, anthropogenic greenhouse gas emissions must decline rapidly, with net zero emissions being reached around 2050. ${ }^{9}$ However, despite several decades of political platitudes, and with climate change mitigation consistently being cited as a key political aim, between 1985 and 2018 the use of fossil fuels increased both in absolute and relative terms. ${ }^{10}$ This has resulted in annual global greenhouse gas emissions continuing to increase, from 20.5 billion tonnes of $\mathrm{CO}_{2}$ in 1990 to 33.3 billion tonnes of $\mathrm{CO}_{2}$ in 2019. ${ }^{11} \mathrm{~A}$ similarly fossil-fuelled development journey for low and middle income countriesincluding the 770 million people without even rudimentary electricity access ${ }^{12}$ would render any efforts to keep global average temperatures below $2{ }^{\circ} \mathrm{C}$ futile. It is therefore evident that the status quo, insofar as emission reductions are concerned, is far from sufficient. A radical departure from conventional responses will be required to address climate change, to build a global community that is, at the same time, more prosperous, more equitable and more sustainable.

However, much of the discourse pertaining to the energy transition betrays an intellectual adherence to a pessimistic 'zero-sum' mentality that threatens to weaken global efforts to decarbonize the world economy in an equitable fashion. This scarcity mindset has resulted in a widespread narrative that contends that it is necessary to take away privileges from those living in high income countries and to limit the growth for those living in low and middle income countries. Historically, this has been reflected in the debate, with arguments being levied against population growth or economic growth on the grounds of environmental protection. This, however, is misguided. Depriving people of a better standard of living will invariably result in public discontent and non-adherence to policies aimed at resolving the challenge at hand. At the core of building a sustainable global community is the provision of a genuinely affordable, clean and on-demand energy system that has as small a footprint (ecological, economic, social) as possible. Nuclear power is at the heart of this new energy system.

Since the first civilian reactors came online in the 1950s, nuclear power has played an important role in providing low carbon, affordable and reliable electricity to communities across the world. Thanks to its low lifecycle emissions, ${ }^{13}$ it is estimated that the use of nuclear power has prevented the emission of 68 billion metric tons of greenhouse gases by displacing mainly coal fired power plants in the period

\footnotetext{
${ }^{7}$ Rockström et al. 2009; Steffen et al. 2015.

${ }^{8}$ https://www.un.org/en/sections/issues-depth/climate-change/. Accessed 1 January 2021.

${ }^{9}$ IPCC 2018.

${ }^{10}$ BP 2020; Ember 2020.

${ }^{11}$ Schlömer et al. 2014.

${ }^{12}$ IEA 2021a, b.

${ }^{13}$ Schlömer et al. 2014.
} 
1970-2015, ${ }^{14}$ and the potential role for nuclear in mitigating climate change has been widely recognized. ${ }^{15}$ The International Energy Agency (IEA) has noted that "[w]ithout action to provide more support for nuclear power, global efforts to transition to a cleaner energy system will become drastically harder and more costly". ${ }^{16}$ However, the potential of nuclear technology goes far beyond climate change mitigation. Thanks to its unique characteristics and broad applications, it should be placed at the centre of policies aimed at combating energy poverty, reducing air pollution, providing clean water, addressing food insecurity, or fulfilling other United Nations SDGs. However, to date, few attempts have been made to fully discern the positive impacts that nuclear technology can have on sustainable development. ${ }^{17}$ This chapter will be exploring the centrality of energy in ensuring sustainable development, and the importance of nuclear energy, which goes beyond simply delivering low carbon electricity. The chapter will be structured thematically, highlighting how nuclear technology provides better health, a better environment and a more just world.

\subsection{The Centrality of (Clean) Energy to Sustainable Development and the Role of Nuclear Energy}

Energy is central to all aspects of life, and many of the most fundamental changes to human lives throughout history have been closely related to breakthroughs in our relationship with energy. These revolutions, whether it is the conquering of fire, the invention of the steam engine, or the advent of electricity, have been associated with major improvements in living standards for many. Despite its undisputed centrality to modern life, energy policymaking is often neglected, and is frequently conducted in a disjointed, crisis-driven and myopic fashion. It is often dictated by short political timeframes (a few years) rather than the generational infrastructure timeframes $(30+$ years) that are usually required. While being only one of 17 SDGs, the seventh United Nations Sustainable Development Goal—Affordable and Clean Energy—underpins most, if not all, SDGs.

Among energy forms, electricity is perhaps the most impactful. Without electricity, it is not possible to genuinely empower people or protect the environment. Without electricity, there cannot be a modern healthcare system, nor universal access to clean water or sanitation, or quality education. There is a clear relationship between

\footnotetext{
${ }^{14}$ IAEA 2018.

${ }^{15}$ Brook 2012; Baek and Pride 2014; Hong et al. 2015; Liddle and Sadorsky 2017; MIT Energy Initiative 2018, 2012; OECD/NEA 2019.

${ }^{16}$ International Energy Agency 2019.

${ }^{17}$ Lindberg (in press).
} 
electricity access and human development, with increasing use of electricity facilitating better quality of life, ${ }^{18}$ and access to low cost clean electricity being essential to reducing socioeconomic inequalities. ${ }^{19}$ There is also solid evidence of the strong connection between electricity access and poverty reduction, ${ }^{20}$ and in particular the positive effects on women's empowerment and welfare. ${ }^{21}$ Electricity breaks the link between daylight and productive time, allowing women to spend less time on domestic chores, making them more likely to get remunerated work, and facilitating higher educational attainment. ${ }^{22}$

Energy is responsible for $73.2 \%$ of global greenhouse gas emissions, of which heat and electricity account for about one third. ${ }^{23}$ In terms of total energy production (electricity, heat, transport), fossil fuels are completely dominant, accounting for $84.3 \%$ of all energy. ${ }^{24}$ Fossil fuels also generate some $63.3 \%$ of global electricity, with low carbon sources accounting for the remainder. As highlighted in a recent IEA report on the global electricity market, the considerable growth in renewable electricity generation has been outpaced by a bigger and faster increase in electricity demand, with the difference (approximately 90\%) being fulfilled by coal fired power plants. ${ }^{25}$ The urgency and the scale of the challenge is striking, especially as in order to limit warming to $1.5{ }^{\circ} \mathrm{C}$, "a virtually full decarbonization of the power sector around mid-century" is required. ${ }^{26}$ Instead, global carbon emissions have increased year by year, only shrinking during times of crisis (e.g. the global recessions of the 1930s, early 1980s and 2008-2009; the end of the Second World War; the collapse of the Soviet Union; and the COVID-19 pandemic). ${ }^{27}$

The enormity of the challenge becomes more dramatic when considering that some 770 million people, predominantly in sub-Saharan Africa, still lack access to electricity, ${ }^{28}$ and that raising the global population's electricity consumption to the European Union average (700 W/person/year), assuming that the global population stagnated, would require an estimated $5000 \mathrm{GW}$ of additional capacity, on top of the existing $2500 \mathrm{GW} .^{29}$ Given the likely increase in electricity demand resulting from the widespread electrification of the economy, it is likely that demand will grow even further.

\footnotetext{
${ }^{18} \mathrm{Niu}$ et al. 2013.

${ }^{19}$ UNECE 2021.

${ }^{20}$ Khandker et al. 2014; Dinkelman 2011; Rao and Pachauri 2017; Karekezi et al. 2012.

${ }^{21}$ Winther et al. 2017.

${ }^{22}$ Khandker et al. 2014.

${ }^{23} \mathrm{https}$ ://www.wri.org/insights/4-charts-explain-greenhouse-gas-emissions-countries-and-sectors. Accessed 1 January 2021.

${ }^{24}$ BP 2020.

${ }^{25}$ International Energy Agency 2021a, b.

${ }^{26}$ Rogelj et al. 2018.

${ }^{27}$ https://www.wri.org/insights/history-carbon-dioxide-emissions. Accessed 1 July 2021.

${ }^{28} \mathrm{https} / / /$ www.iea.org/reports/sdg7-data-and-projections/access-to-electricity. Accessed June 2021.

${ }^{29}$ Devanney 2021.
} 
Too often, policy discourse focuses almost exclusively on decarbonization and is marked by the notion of 'energy as a constraint'. This misguided notion manifests itself in a multitude of ways, most notably the perceived need to reduce energy consumption due to its unsustainability. In many ways, energy should rather be seen as a driver to affect socioeconomic change, given its importance in all facets of modern life. In addressing climate change, there is a window of opportunity to decarbonize the global economy, and at the same time create a more sustainable and equitable global society. While intermittent electricity access (e.g. through off-thegrid solar panels) represents a step in the right direction, it is more than evident that it is not sufficient to power a modern economy. ${ }^{30}$ For the transition to a low carbon global society to be considered equitable, it is crucial that reliable, around-the-clock, non-polluting energy portfolios are developed to match the needs and the natural endowments of each nation.

Nuclear energy provides low and middle income countries an opportunity to fundamentally transform their energy systems in a sustainable fashion, leapfrogging the carbon intensive pathways travelled historically by developed countries. Nuclear energy has proven that it is possible to disassociate economic growth and greenhouse gas emissions, as highlighted by Sweden ${ }^{31}$ and France ${ }^{32}$. Indeed, the rapid expansion of nuclear power in both Sweden and France from 1960 onwards showcased that it is possible to rapidly transform the electricity systems of developed industrial economies from being largely reliant on fossil fuels to becoming some of the lowest emitting in the world within 20 years $^{33}$ - similar to the timeframes set by the 2015 Paris Agreement to avoid the worst effects of climate change. Modelling concludes that a global expansion of nuclear power at these historic rates would see fossil fuels displaced from the global electricity system within the required timeframes. ${ }^{34}$

Nuclear energy is the only low carbon energy source that can produce not only electricity but also heat. This brings enormous opportunities to decarbonize other hard-to-abate sectors of the economy. While climate change may result in warmer winters in many parts of the world, heating for buildings will remain crucial, and surplus heat from nuclear power plants is already used across the world, for instance in Switzerland, the Russian Federation and China, ${ }^{35}$ to provide district heating in nearby cities. Additionally, there are efforts in China and Finland to explore the possibility of building small reactors specifically for the purposes of generating heat for building conditioning. ${ }^{36}$ Nuclear energy can also be used to generate the heat that is indispensable for many industrial processes, such as the production of

\footnotetext{
${ }^{30}$ Clack et al. 2017; Heard et al. 2017.

${ }^{31}$ Lindberg 2017.

${ }^{32}$ World Nuclear Association 2019.

${ }^{33}$ Cao et al. 2016.

${ }^{34}$ Qvist and Brook 2015.

${ }^{35}$ Csik and Kupitz 1997; Jasserand and Devezeaux de Lavergne 2016; https://www.world-nuclearnews.org/Articles/Haiyang-begins-commercial-scale-district-heat-supp. Accessed 1 July 2021.

${ }^{36}$ Värri and Syri 2019.
} 
concrete, steel and paper, as well as in the chemical industry, ${ }^{37}$ and the production of hydrogen and synthetic fuels ${ }^{38}$ for shipping and transport. Specifically built reactors that operate at higher temperatures, or retrofitting nuclear reactors into existing coal fired power plants to reuse existing infrastructure, have been suggested as potential ways to decarbonize these other sectors of the economy. ${ }^{39}$

Beyond providing zero-carbon electricity and heat for clean affordable energy, nuclear technologies directly contribute in a myriad of ways towards the global efforts to reach many of the SDGs, including Goals 2 (zero hunger), 3 (good health and well-being), and 6 (clean water and sanitation) to ensure a healthier world.

\subsection{Nuclear Technology for Better Health}

One of the most fundamental requirements for realizing human potential is good health, and access to efficient and affordable healthcare is critical to this. The global coronavirus pandemic has focused attention on public health in an unprecedented fashion, and it has in very stark terms highlighted the vast health inequalities that exist globally, as well as within individual countries. Access to reliable, around-theclock and clean electricity plays an important role in strengthening public health both directly and indirectly. The provision of good public health goes beyond powering medical facilities, and includes protecting children's lungs from the known dangers of air pollution, fighting communicable diseases such as sleeping sickness and noncommunicable diseases such as cancer, the provision of safe drinking water, and combating starvation and food insecurity. Nuclear technology has for decades played a major role within all of these areas, and it is a role that should be greatly expanded to improve the health of every man, woman and child across the world, irrespective of their location.

\subsubsection{Cleaner Air with Nuclear Power}

Air pollution is a major public health issue afflicting communities across the world, playing a major role in the development of illnesses such as chronic pulmonary disease, ischaemic heart disease, haemorrhagic and ischaemic strokes, and lower respiratory infections. Air pollution is often associated with polluting energy sources, be it dirty cooking fuels or the use of polluting fuels for electricity generation, as well as combustion engines. The Global Burden of Diseases, Injuries, and Risk Factors Study 2015 ranks air pollution (indoor and ambient) as a leading cause of

\footnotetext{
${ }^{37}$ Royal Society 2020.

${ }^{38}$ Ingersoll and Gogan 2020.

${ }^{39}$ Qvist et al. 2021.
} 
illness, ${ }^{40}$ with some $91 \%$ of the global population being exposed to air that exceeds the World Health Organization's (WHO) air quality guidelines. ${ }^{41}$ This has detrimental impacts on public health globally, with air pollution contributing to approximately $9 \%$ of all deaths worldwide, with low and middle income countries-especially in South and East Asia-being worse affected. ${ }^{42}$ The WHO estimates that ambient air pollution significantly contributes to 4.2 million premature deaths per year, with some 3.8 million premature deaths resulting from indoor air pollution, ${ }^{43}$ while some studies estimate that the use of fossil fuels contributed to some 8.7 million premature deaths in 2018 alone. $^{44}$

Much of the indoor air pollution can be eliminated if solid fuels (e.g. wood, dung, charcoal) and kerosene were replaced with electricity for cooking, and if that electricity came from low carbon power sources, a considerable amount of the ambient air pollution would be avoided too. Air pollution is currently especially prevalent in low and middle income countries, ${ }^{45}$ which is also where most of the growth in electricity demand is expected to occur. Currently, over 2.6 billion people across the world do not have access to clean cooking facilities (with only $17 \%$ of the population in sub-Saharan Africa having access, ${ }^{46}$ relying on biomass, coal or kerosene). Thus, transitioning to a clean electric system offers an important opportunity to not only prevent many millions of premature fatalities, but also to safeguard local forests.

Nuclear power has played an important role in protecting local communities from the known dangers of air pollution for decades, owing to the fact that nuclear power plants do not emit any air pollution. A study conducted by Kharecha and Hansen in 2013 estimated that the use of nuclear energy between 1971 and 2009 had prevented some 1.8 million air pollution related deaths, ${ }^{47}$ either by replacing more polluting energy sources, or rendering such sources unnecessary. The impacts of nuclear energy on air pollution can also be seen in places where nuclear power plants have been prematurely closed for political reasons, as was the case in Germany following the accident at the Fukushima Daiichi nuclear power plant in 2011. It has been estimated that between 2010 and 2017, the German nuclear phaseout resulted in an additional 1,100 air pollution related deaths annually, driven largely by the fact that nuclear power was to a significant degree replaced by coal. ${ }^{48}$ Therefore, it is crucial that existing reactors continue to operate for as long as they are capable of doing so, and

\footnotetext{
${ }^{40}$ Cohen et al. 2017.

${ }^{41} \mathrm{https}: / /$ www.who.int/news-room/fact-sheets/detail/ambient-(outdoor)-air-quality-and-health. Accessed 12 June 2021.

${ }^{42} \mathrm{https}$ ///ourworldindata.org/air-pollution\#air-pollution-is-one-of-the-world-s-leading-risk-fac tors-for-death. Accessed 1 July 2021.

${ }^{43} \mathrm{https}: / /$ www.who.int/health-topics/air-pollution\#tab=tab_1. Accessed 12 June 2021.

${ }^{44} \mathrm{https} / / /$ www.iea.org/reports/sdg7-data-and-projections/access-to-clean-cooking. Accessed 15 June 2021.

${ }^{45} \mathrm{https}$ ://ourworldindata.org/air-pollution\#air-pollution-is-one-of-the-world-s-leading-risk-fac tors-for-death. Accessed 1 July 2021.

${ }^{46}$ Kharecha and Hansen 2013.

${ }^{47}$ Jarvis et al. 2019.

${ }^{48}$ Vohra et al. 2021.
} 
that nuclear power is expanded to low and middle income countries to displace fossil fuel-fired electricity generation.

\subsubsection{Combating Cancer and Other Diseases}

Radiation has been used in modern medicine for many decades for the diagnosis and treatment of many conditions, but it is most intimately associated with the treatment of cancer. Few, if any, diseases hold as emotive a place in human society as cancer. The earliest mention of cancers can be found in papyruses that are more than 5000 years old, and the term was initially coined by Hippocrates (460-370 BC). ${ }^{49}$ Cancer is one of the most common diseases, with more than 14 million new cases diagnosed each year. ${ }^{50}$ Approximately $20 \%$ of all men and $17 \%$ of all women are diagnosed with cancer during their lifespan, ${ }^{51}$ but these figures vary country to country. However, as life expectancy rises, so does the risk of cancer ${ }^{52}$ — with, for example, a $40 \%$ lifetime risk in the United States of America ${ }^{53}$ and a risk of approximately $50 \%$ in the United Kingdom. ${ }^{54}$

Radiation plays a tremendously important role in combating cancers around the world. Radiotherapy — often using radioactive elements produced in reactors - can be used in approximately $50 \%$ of all cancer cases, for curative or palliative purposes. ${ }^{55}$ Some radiotherapy techniques allow addressing conditions difficult to handle in any other way, such as the Leksell Gamma Knife that can destroy cancers in places difficult to reach surgically, such as the brain, by concentrating a large number of small external radiation beams into the target tumour. Early imaging techniques such as $\mathrm{X}$ rays revolutionized medicine, but current nuclear imaging techniques, such as computed tomography (CT or CAT), single photon emission computed tomography (SPECT) or positron emission tomography (PET), which provide 3-D images and allow doctors to see bones and tissues and assess organ functionality, represent a step change in our ability to diagnose and cure disease. Additional diagnostic methods include real-time RT-PCR, which is a nuclear derived diagnosis method that detects potential pathogens in a few hours, as opposed to days, including viruses such as COVID-19 or Ebola. More than 40 million nuclear medicine procedures are performed each year, and demand for radioisotopes is increasing at up to $5 \%$ annually.

Another important application of nuclear technology for delivering better human health globally is the Sterile Insect Technique (SIT). Some 17\% of all infectious

\footnotetext{
${ }^{49}$ American Cancer Society 2014.

${ }^{50}$ Jaffray and Gospodarowicz 2015.

${ }^{51}$ WHO 2018.

${ }^{52}$ International Agency for Research on Cancer 2020.

${ }^{53}$ American Cancer Society 2020.

${ }^{54}$ Smittenaar et al. 2016.

${ }^{55}$ Jaffray and Gospodarowicz 2015.
} 
diseases globally are vector-borne, including malaria, yellow fever, dengue fever and Zika. ${ }^{56}$ Owing to climate change, it is likely that vector-borne and zoonotic diseases will spread beyond their current ranges; indeed, there is evidence of this already taking place. ${ }^{57}$ This problem may be exacerbated as mosquitoes and other vectors build resistance against most commonly used insecticides. ${ }^{58}$ SIT uses radiation from radioactive sources, such as Cobalt-60 or Caesium-137, to sterilize a large number of male target pests (e.g. Tsetse flies or Anopheles mosquitoes) that are subsequently released into the environment. As these males will not be able to successfully breed, the pest population will be radically reduced or eradicated, and by extension the risk of human infection of any vector-borne diseases will be significantly decreased. ${ }^{59}$ SIT has been used successfully around the world to control pests that act as vectors for a large number of diseases ${ }^{60}$-including myiasis (caused by Screwworm flies) and African trypanosomiasis (caused by Tsetse flies) — and could play a major role in combating mosquito-borne diseases such as malaria and dengue fever. ${ }^{61}$ SIT also replaces or reduces the need for pesticides, which often have additional health and environmental consequences.

\subsubsection{Providing Fresh and Clean Water with Nuclear Technology}

Water is the key to virtually all life on the planet, and the crucial role of water for humanity cannot be overstated. The global demand for water has grown steadily, whereas existing reserves of fresh water have shrunk, ${ }^{62}$ and it is expected that climate change will have negative impacts on water resources globally, exacerbating water scarcity. ${ }^{63}$ Water is an unevenly distributed resource and two thirds of the global population already experience severe water scarcity for at least one month every year, ${ }^{64}$ and more than 1.4 billion people (of which 450 million are children) live in areas with high or extremely high water vulnerability. ${ }^{65}$ This is also compounded by the lack of safe drinking water, which was responsible for an estimated 1.2 million fatalities in $2017,{ }^{66}$ with diarrhoeal diseases such as cholera and dysentery killing

\footnotetext{
${ }^{56}$ WHO and IAEA 2020.

${ }^{57}$ Higgs 2018, p. 285.

${ }^{58}$ Bouyer et al. 2020.

${ }^{59}$ Klassen and Vreysen 2021.

${ }^{60} \mathrm{Klassen}$ et al. 2021.

${ }^{61}$ Klassen 2009.

${ }^{62}$ Boretti and Rosa 2019.

${ }^{63}$ Jiménez Cisneros et al. 2014.

${ }^{64}$ Mekonnen and Hoekstra 2016.

${ }^{65}$ UNICEF 2021.

${ }^{66} \mathrm{https}$ ://ourworldindata.org/water-access\#unsafe-water-is-a-leading-risk-factor-for-death. Accessed 1 July 2021.
} 
almost 500,000 people annually. ${ }^{67}$ Unfortunately, UN-Water recently concluded that not enough progress has been made towards meeting SDG 6 (clean water and sanitation), with water sources drying up and/or becoming even more polluted. ${ }^{68}$ Nuclear radiotracers are an essential tool for the surveying of groundwater resources, to identify and map their origin, distribution, quantity and quality, and to develop sensible and sustainable plans for their exploitation and management. These same nuclear techniques are used to assess and manage seawater leaks into freshwater aquifers, to study ecosystem dynamics, to track pollutants in water streams and to analyse the effectiveness of pollution control and remediation techniques. ${ }^{69}$

An important tool for ensuring a steady supply of potable water for homes and industry alike is desalination of seawater. There are currently some 16,000 desalination facilities worldwide, with the majority of them located in the Middle East. Desalination requires considerable amounts of energy to operate, and when reliant on fossil energy sources (which often is the case), it results in a considerable emissions footprint. ${ }^{70}$ Unless the cost of fresh water from desalination facilities can be made comparable to the cost of water from traditional sources, ${ }^{71}$ many of the world's most climate-vulnerable communities, some 700 million people, will be forced to relocate by $2030 .{ }^{72}$ Increasing water demands in combination with the need for decarbonization mean that nuclear energy presents a suitable alternative to fossil fuels to power desalination facilities. ${ }^{73}$ This could be done either by coupling large power reactors with desalination plants as an additional application, or using reactors dedicated to desalination. ${ }^{74}$ Nuclear desalination is by no means a novel application, with some 200 reactor years' worth of experience amassed, mostly on a smaller scale, especially in Japan, India and Kazakhstan. ${ }^{75}$ It is also a concept that has been widely researched, and the combination of empirical testing and feasibility studies has proven that nuclear desalination is both technically and economically achievable. ${ }^{76}$ For instance, scientific studies suggest that a nuclear desalination programme in China — which already suffers from water scarcity ${ }^{77}$ — would be able to significantly increase water resources in areas of scarcity, and at affordable levels. ${ }^{78}$

\footnotetext{
${ }^{67}$ https://www.who.int/news-room/fact-sheets/detail/drinking-water. Accessed 1 July 2021.

${ }^{68}$ UN-Water 2021.

${ }^{69}$ IAEA 2015.

${ }^{70}$ Jones et al. 2019; Darre and Toor 2018.

${ }^{71}$ Ziolkowska 2015.

${ }^{72} \mathrm{https} / / /$ www.unicef.org/wash/water-scarcity. Accessed 25 June 2021.

${ }^{73}$ Ingersoll et al. 2014a.

${ }^{74}$ Ingersoll et al. 2014b.

${ }^{75}$ https://www.iaea.org/topics/non-electric-applications/nuclear-desalination. Accessed 1 January 2021.

${ }^{76}$ Belessiotis et al. 2010.

${ }^{77}$ Jiang 2009.

${ }^{78}$ Avrin et al. 2015, 2018.
} 


\subsubsection{Combating Hunger with Nuclear Technology}

Some 768 million people (2020) suffer from hunger, ${ }^{79}$ and every year, undernutrition is either the direct or underlying cause of $45 \%$ of all deaths among children. ${ }^{80}$ Additionally, more than one in five children under the age of five (some 144 million children) are stunted, and while the pandemic has resulted in increased levels of food insecurity, the pre-pandemic trend already saw a food insecurity increase of $3.2 \%$ between 2014 and $2018 .^{81}$ At the same time, approximately 1.3 billion tonnes of food are wasted every year, either by consumers or retailers, or become spoiled as a result of poor storage, transportation or harvesting practices. ${ }^{82}$

Electricity is a vital component in eliminating world hunger, helping to increase food production, decrease post-harvest losses, and enable better storage of food (including refrigeration). ${ }^{83}$ Empirical studies have concluded that access to electricity has an immediate positive effect on food security, especially in terms of food production, conservation and preparation. ${ }^{84}$ Nuclear power already plays a major role in providing pollution-free electricity, and in combination with other nuclear technologies, can play a crucial role in combating hunger worldwide, thus meeting the second of the SDGs.

Nuclear techniques can be used to promote more efficient use of water and nutrients by crops, ensuring increased agricultural yields, leaving more space for nature. One such nuclear technology is food irradiation, where foodstuffs are exposed to carefully controlled amounts of radiation, often using Cobalt-60 manufactured in nuclear reactors, to kill disease causing fungi, parasites and bacteria. The process significantly increases the shelf-life of food, helping to avoid wastage. ${ }^{85}$ Equally important from a public health perspective, food irradiation can also play a large role in tackling food-borne diseases, which cause more than 420,000 deaths annually_deaths that disproportionately impact children under the age of five. Additionally, food-borne diseases can cause long lasting health detriments, and cost low and middle income countries US $\$ 110$ billion in lost productivity and medical expenses each year. ${ }^{86}$ Food irradiation has been approved by the WHO, the Food and Agricultural Organization, and the United States Food and Drug Administration ${ }^{87}$ and

\footnotetext{
${ }^{79} \mathrm{FAO}$ et al. 2021.

${ }^{80}$ Mark et al. 2020.

${ }^{81}$ https://sdgs.un.org/goals/goal2. Accessed 1 July 2021.

${ }^{82}$ UNEP 2020.

${ }^{83}$ Willcox et al. 2015.

${ }^{84}$ Candelise et al. 2021.

${ }^{85}$ Verma and Gautam 2015; Thayer 1993.

${ }^{86} \mathrm{https}$ ://www.who.int/NEWS-ROOM/FACT-SHEETS/DETAIL/FOOD-SAFETY. Accessed 1 July 2021.

${ }^{87}$ WHO 1994; WHO 1988; https://www.fda.gov/food/buy-store-serve-safe-food/food-irradiationwhat-you-need-know. Accessed 1 July 2021.
} 
although it is currently employed in more than 60 countries around the world, ${ }^{88}$ there are enormous opportunities to increase its use.

A further application of nuclear technology to reduce food insecurity and hunger is the aforementioned SIT. Some $20-40 \%$ of crop yields are lost every year because of different pests and diseases. ${ }^{89}$ Such losses are likely to be exacerbated by climate change $^{90}$ at a time when food production will need to increase by almost $50 \%$ to meet growing demand. ${ }^{91}$ SIT programmes around the world have demonstrated the value of the technique in terms of controlling pests (e.g. fruit flies) and preventing their spread to new areas. The technique is cost effective and environmentally friendly as it helps to reduce pesticide and fertilizer use, both of which are associated with health and environmental risks. ${ }^{92}$

\subsection{Protecting the Environment with Nuclear Energy}

\subsubsection{Habitat Destruction and Biodiversity Loss}

One consequence of our developmental journey is the largely unprecedented loss of biodiversity that has taken place over the past 500 years, with the rate of extinction being almost 100 times higher than expected. ${ }^{93}$ There is now little doubt that both extinction of entire species and population declines are largely anthropologically driven, and their magnitude and rate are comparable to the previous five major extinction events that have taken place in the past 450 million years. ${ }^{94}$ Between 1970 and 2016 , there was a $68 \%$ average decline in population sizes amongst mammals, fish, reptiles, amphibians and birds, ${ }^{95}$ and this trend was seen amongst both 'traditionally' vulnerable species (e.g. apex predators) as well as species of low concern. ${ }^{96}$ This decline has been largely driven by changes to, or outright destruction of, natural habitats, with $75 \%$ of the planet's ice-free surface having been significantly altered by human action ${ }^{97}$ directly through overexploitation and indirectly through the effects of climate change. ${ }^{98}$ The loss of biodiversity threatens to have considerable consequences on the long term stability and dynamics of ecosystems which, in turn, could

\footnotetext{
${ }^{88}$ https://www.iaea.org/topics/food-irradiation. Accessed 1 July 2021.

${ }^{89}$ http://www.fao.org/news/story/en/item/1187738/icode/. Accessed 1 July 2021.

${ }^{90}$ IPPC Secretariat 2021.

${ }^{91}$ FAO 2017.

${ }^{92}$ Enkerlin 2005.

${ }^{93}$ Ceballos and Ehrlich 2018.

${ }^{94}$ Dirzo et al. 2014.

${ }^{95}$ WWF 2020.

${ }^{96}$ Ceballos et al. 2017.

${ }^{97}$ WWF 2020.

${ }^{98}$ Intergovernmental Science-Policy Platform on Biodiversity and Ecosystem Services 2019.
} 
result in secondary impacts such as disruptions to food production (as a result of increased pest density or decrease in pollinators $)^{99}$ and environmental degradation (in turn associated with forced migration and increased emergence of infectious diseases, for example). ${ }^{100}$

A crucial step to stop biodiversity loss is to alleviate the pressures posed by habitat destruction, climate change and unsustainable exploitation on local environments and species. ${ }^{101}$ Energy, both in terms of access and source, plays a crucial role in causing these pressures. For instance, there is a direct relationship between forest degradation (and deforestation) and energy access. Where people either entirely lack access to electricity — or do not have enough of it - they often rely on biomass (often collected from local forests) for fuel. This not only damages local habitats and contributes to decreasing biodiversity, but is also a major source of household air pollution. An extensive analysis of some 158 countries looking at deforestation and rural access to electricity found that rural electrification plays a very significant role in reducing deforestation as electricity replaces biomass. ${ }^{102}$ This again highlights not only the scale of the challenge or the many benefits of ensuring rural electrification, but also the great increase in electricity demand that will be an inevitable consequence of replacing biomass with electricity.

\subsubsection{More Space for Nature}

Meeting this energy demand will require all available low carbon energy sources, but from an environmental conservation viewpoint, nuclear energy is the most benign. The key to nuclear power's conservation value is its very small physical footprint. By virtue of the energy density inherent to nuclear fuel, nuclear power plants have much smaller physical footprints than all other low carbon energy sources. Indeed, a single uranium fuel pellet (weighing roughly $10 \mathrm{~g}$ ) contains the equivalent energy of three barrels of oil (149 gallons), one tonne of coal or $481 \mathrm{~m}^{2}$ of fossil gas. ${ }^{103}$ The energy density of nuclear fuels, and the extremely high capacity factor of nuclear reactors (global average $82.5 \%$ in 2019, with many individual reactors at over $90 \%$ ) in comparison to other energy sources (solar photovoltaic (PV) $18 \%$ in 2019, onshore wind $35 \%$ in 2019 , offshore wind $43.5 \%$ in 2019 , coal $49 \%$ in 2019 , fossil gas 29 $63 \%$ in 2018) means that a nuclear centric energy system would require significantly less land than any energy system that is highly-or entirely-reliant upon intermittent renewables. ${ }^{104}$ An average sized (1000 MWe) nuclear reactor, capable of

\footnotetext{
${ }^{99}$ Tscharntke et al. 2012.

${ }^{100}$ Schmeller et al. 2020.

${ }^{101}$ Ceballos et al. 2015.

${ }^{102}$ Tanner and Johnston 2017.

${ }^{103}$ https://www.nei.org/fundamentals/nuclear-fuel. Accessed 1 July 2021.

${ }^{104}$ World Nuclear Association 2020; https://www.energy.gov/ne/articles/what-generation-capacity. Accessed 1 July 2021; https://www.irena.org/Statistics/View-Data-by-Topic/Costs/Global-Trends.
} 
powering over two million homes in Europe, occupies approximately $3.4 \mathrm{~km}^{2}$ and is able to generate electricity $90-95 \%$ of the time. In contrast, a solar farm with the same installed capacity (1000 MWe) would occupy $194 \mathrm{~km}^{2}$, with the equivalent wind farms occupying between 673 and $963 \mathrm{~km}^{2} .{ }^{105}$ Given that renewable power sources generate electricity only part of the time, and also require backup generation, the physical footprint of an energy system highly or entirely dependent on intermittent renewables could contribute considerably to both environmental degradation and habitat loss. With a larger physical footprint, there is an increased risk of interference with the natural environment. Indeed, it is well established that these installations can have a detrimental impact on local wildlife, in terms of direct mortality (e.g. impact trauma, entrapment, burning), indirect mortality (e.g. predation due to habitat changes, increased competition), and habitat degradation or loss. ${ }^{106}$ The IEA highlighted in their recent Net Zero by 2050 report that in order to meet the stated policy goals by 2050, an unprecedented expansion of both solar and wind will be required; by 2030, some $630 \mathrm{GW}$ of solar PV and $390 \mathrm{GW}$ of wind would have to be installed annually-four times above the levels in 2020. ${ }^{107}$ For solar PV, this would require installing the equivalent of the world's largest solar farm every single day. As of July 2021, the world's largest commissioned solar farm - the Bhadla Solar Park in Rajasthan, India-occupies an area of 14,000 acres $\left(\sim 57 \mathrm{~km}^{2}\right) .{ }^{108}$ This would mean that in the next ten years, solar farms with a cumulative size slightly larger than the country of Belarus, approximately $208,000 \mathrm{~km}^{2}$, would have to be constructed.

Nuclear power plants not only occupy considerably less space than any other low carbon energy sources, but also use the materials needed in a very resource efficient manner, thanks in part to the longevity of the reactors ( 80 years +$)^{109}$ in comparison to wind turbines (20 years) $)^{110}$ and solar panels (depending on type, 5-35 years). ${ }^{111}$ Invariably, the construction of any energy infrastructure requires materials-from concrete to an array of different metals and minerals - and these materials have an environmental footprint that needs to be taken into account. Nuclear reactors use about ten times less critical minerals than solar/TWh, and between 10-15 times less than wind power/TWh. ${ }^{112}$ The type of materials used plays a major contributory role in determining the potential environmental (and health) impacts. Wind turbines and solar panels require considerable amounts of rare earth elements and heavy

Accessed 1 July 2021; International Energy Agency 2020; https://www.iea.org/data-and-statistics/ charts/average-annual-capacity-factors-by-technology-2018. Accessed 1 July 2021.

105 https://www.nei.org/news/2015/land-needs-for-wind-solar-dwarf-nuclear-plants. Accessed 1 July 2021; Stevens 2017.

${ }^{106}$ Chock et al. 2021.

${ }^{107}$ International Energy Agency 2021a, b.

${ }^{108}$ https://www.nsenergybusiness.com/features/largest-solar-power-plants/. Accessed 1 July 2021.

${ }^{109}$ https://www.energy.gov/ne/articles/whats-lifespan-nuclear-reactor-much-longer-you-mightthink. Accessed 1 July 2021.

${ }^{110}$ Ziegler et al. 2018.

${ }^{111} \mathrm{http}: / /$ solarenergyforus.com/solar-panel-efficiency-lifespan/. Accessed 1 July 2021.

${ }^{112}$ International Energy Agency (2021) and International Energy Agency (2021). 
metals mostly (90\%) produced in China, ${ }^{113}$ and these mining operations have well established and considerable negative environmental and public health impacts. ${ }^{114}$

Furthermore, the unprecedented expansion of renewable energy capacity that would be required - and the considerable amount of physical space needed-faces a major challenge and potential barrier: public acceptance. While public opinion polls at the national level generally find high levels of support, ${ }^{115}$ the picture is often very different at the local level. There are already signs of growing opposition among potential host communities, both in terms of hosting renewable installations and the transmission infrastructure that invariably will be required. Such local opposition is often on the grounds of visual impact, (perceived or actual) inequitable distribution of costs and benefits, fears relating to adverse effects on the local economy, impacts on wildlife, or issues related to its footprint (land use). ${ }^{116}$

One of the fundamental principles of ensuring a just energy transition is the safeguarding of self-determination of local communities, with guarantees that only willing communities would act as hosts of any energy infrastructure. The sheer scale of the renewables expansion required, and the fact that public opposition is already rising, are concerns that must be taken into account when designing energy policies for the future. Utilizing a sizeable nuclear component in any future energy system would significantly limit the impact of energy infrastructure on local communities. The key factor is energy density, with nuclear power plants being capable of generating vast amounts of electricity with a footprint of an order of magnitude similar to, or smaller than all other low carbon energy sources.

\subsection{Ensuring a Just Energy Transition}

It is essential that transitions to clean energy systems are done in a way that means no one is left behind, both on an individual level, on a sector level, as well as on a country level. Indeed, the provision of robust energy infrastructure is essential to ensuring that countries thrive, rather than simply subsist. The energy transition does provide a great opportunity to create wealth and prosperity for everyone on the planet, but thought leadership and an abundance mindset will be needed to make the most of this opportunity. Nuclear energy has a central role to play in ensuring a just energy transition, and it is essential that no unreasonable constraints-political, legislative, financial or otherwise - are placed on the expansion of nuclear technologies to low and middle income countries that wish to incorporate this technology in their energy mix.

\footnotetext{
${ }^{113}$ Van Gosen et al. 2017.

${ }^{114}$ Lee and Wen 2017; Arshi et al. 2018.

${ }^{115}$ Tyson et al. 2021; Department for Business, Energy, and Industrial Strategy 2021; https://ec.eur opa.eu/clima/citizens/support_en. Accessed 1 July 2021.

${ }^{116}$ Gross 2020; Goyal et al. 2021; O’Neil 2021; https://www.cleanenergywire.org/factsheets/fig hting-windmills-when-growth-hits-resistance. Accessed 1 July 2021.
} 


\subsubsection{Nuclear Energy Strengthening Energy Independence}

Since energy and electricity are fundamental to every facet of modern life, securing supplies that are secure and resilient to external pressures should be a priority for governments. Indeed, throughout history there is ample evidence to suggest that States use energy as a political tool (e.g. the 1973 Oil Crisis) to maintain, exert and expand their spheres of influence. ${ }^{117}$ Such actions can have, and have had, considerable political, socioeconomic and humanitarian consequences. In transitioning to clean energy systems, it is crucial that these new systems promote social, economic and political stability, and ensure a large degree of national independence and resiliency. A diversified energy mix that includes nuclear energy helps to ensure self-reliance.

Nuclear energy does not use large amounts of strategic raw materials and its fuel, uranium, can be found in many parts of the world. ${ }^{118}$ Furthermore, the prospects of refining naturally occurring uranium from seawater ${ }^{119}$ or using abundant thorium as fuel $^{120}$ are being explored. Uranium is not only a relatively abundant material (it is the 48th most common element on Earth, approximately 1000 times more common than gold), it is also found in many countries around the world. The pervasive nature of nuclear fuel deposits - unlike fossil gas or rare earth elements that are only found in a small number of countries - means that the geopolitical risks of the nuclear fuel supply chain are considerably lower than energy systems reliant on fossil gas ${ }^{121}$ or renewable energy. ${ }^{122}$ The cost of uranium has been historically low, partly driven by its relative abundance and partly driven by the few competing uses of uranium. Additionally, the cost of nuclear electricity is relatively insensitive to the price of uranium (a doubling of uranium prices would result in a $10 \%$ increase in electricity price). ${ }^{123}$

\footnotetext{
${ }^{117}$ Directorate-General for External Policies of the Union (European Parliament) 2018.

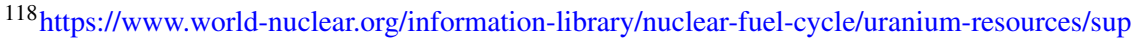
ply-of-uranium.aspx. Accessed 1 July 2021.

${ }^{119} \mathrm{https} / / / \mathrm{www} . \mathrm{scientificamerican.com/article/uranium-extraction-from-seawater-takes-a-major-}$ step-forward/. Accessed 1 July 2021.

${ }^{120} \mathrm{https}$ ://world-nuclear.org/information-library/current-and-future-generation/thorium.aspx. Accessed 1 July 2021.

${ }^{121} \mathrm{https}$ ://world-nuclear.org/information-library/economic-aspects/energy-security.aspx. Accessed 1 July 2021.

${ }^{122}$ Habib et al. 2016; Stegen 2015.

${ }^{123} \mathrm{https}$ ://world-nuclear.org/information-library/economic-aspects/economics-of-nuclear-power. aspx. Accessed 1 July 2021.
} 


\subsubsection{Minimizing the Legacy for Future Generations}

Every industrial process invariably generates some form of waste. Indeed, some of the greatest challenges that humanity faces, such as climate change, are caused by waste management failures. Central to ensuring a just clean energy transition is minimizing its legacy footprint, both in the amount and longevity of waste. Such a holistic approach is crucial to ensuring that potentially short sighted policies aimed at resolving today's problems do not create potentially greater harms for future generations. Among low carbon energy sources, nuclear energy is the only industry that since its inception has strived to manage its waste streams throughout its lifecycle and internalize all costs in the price of nuclear electricity. Nuclear power plants have amongst the smallest raw material requirements per unit of electricity generated, which results in the smallest waste footprint. An average sized (1000 MWe) nuclear reactor discharges approximately 25-30 metric tonnes of used nuclear fuel each year, ${ }^{124}$ and since the first nuclear unit came online in the late 1950 s, the entire industry has discharged an estimated total 400,000 tonnes of used nuclear fuel, with approximately $30 \%$ of this material having been recycled for reuse in reactors. ${ }^{125}$ The equivalent coal fired power plant generates on average 275,000 tonnes of toxic ash per year (containing, for example, mercury, arsenic and beryllium), on top of more than 3 tonnes of carbon dioxide. Similarly, it is estimated that by 2050 some 60-78 million tonnes of electronic waste will have been generated by the use of solar $\mathrm{PV},{ }^{126}$ with analysis suggesting that the actual figure might be considerably higher as solar panels are prematurely replaced. ${ }^{127}$ Solar waste often contains toxic materials such as cadmium, antimony and lead, and the glass that makes up the majority of the panel can rarely be recycled due to impurities, meaning that panels often end up in landfills, or are exported to low and middle income countries as electronic waste. If the panels break, toxic materials can leach into the local environment, with potentially detrimental health impacts. ${ }^{128}$ In contrast, most nuclear waste can be recycled, including the used nuclear fuel. Recycling of nuclear materials is common practice in the nuclear industry, and extensive efforts are currently underway to further reduce nuclear power's already small waste footprint. The main thrust in this field is research and commercialization of so-called 'burner reactors' which are capable of being powered by used fuel from the current nuclear reactor fleet, thus reducing the overall amount of nuclear waste by $97 \%$.

Its small waste legacy and effective use of natural resources makes nuclear power an integral tool in ensuring that a just energy transition can take place. Indeed, civil

\footnotetext{
${ }^{124} \mathrm{https} / / /$ world-nuclear.org/information-library/nuclear-fuel-cycle/nuclear-wastes/radioactivewastes-myths-and-realities.aspx. Accessed 1 July 2021.

${ }^{125}$ IAEA 2020.

${ }^{126}$ International Renewable Energy Agency, International Energy Agency Photovoltaic Power Systems 2016.

${ }^{127}$ https://hbr.org/2021/06/the-dark-side-of-solar-power. Accessed 1 July 2021.

${ }^{128} \mathrm{https}$ ://www.discovermagazine.com/environment/solar-panel-waste-the-dark-side-of-cleanenergy. Accessed 1 July 2021.
} 
nuclear waste is managed to the highest standards and has not caused any harm to people or the environment. With nuclear waste repositories now being constructed, the nuclear industry can demonstrate that long term management solutions are readily available.

\subsubsection{An Affordable and Value-Creating Transition with Nuclear Energy}

The question of cost-effectiveness is integral to ensuring a just energy transition. The design of the energy systems of the future must optimize the use of available resources-financial, human and material-to deliver reliable, around-the-clock, affordable and clean energy to all sectors of the economy. Any solutions must represent genuine value for money, be long lasting, and result in socioeconomic spillovers for the local, national and regional economies. ${ }^{129}$ For example, studies from the IEA, the MIT Energy Initiative, the OECD's Nuclear Energy Agency and others have found that achieving the same low carbon emissions with a larger contribution of nuclear generation makes the total cost of electricity for the end consumer or the taxpayer more affordable compared with a generation mix that relies on a large share of variable renewable energy. ${ }^{130}$

The low carbon energy sector, and nuclear energy in particular, can play a major role in terms of job creation and leading the efforts towards building a more sustainable and resilient future. Investment in the nuclear sector has a proven track record of contributing to socially sustainable and equitable economic development, while helping to create reliable low carbon modern energy systems that offer resilience with regards to weather fluctuations or future geopolitical and economic shocks. The development of nuclear power has historically proven to be a catalyst for industrial and economic growth and prosperity across the world. Countries with limited domestic energy resources such as France, Japan and Republic of Korea are excellent examples of how nuclear energy delivers widespread growth along with energy independence, security of supply and resilience against geopolitical shocks.

Nuclear energy generates a significant amount of highly skilled, highly paid, and mostly local jobs for an extended period of time, often for 80-100 years when including construction, operations and decommissioning. Putting nuclear energy at the heart of a modern industrial strategy will provide support for skills development, R\&D, and trade and investment. Analysis of the European nuclear industry has found that every direct job created by the nuclear industry generates work for an additional 3.2 people. ${ }^{131}$ It is estimated that every euro spent in the European

\footnotetext{
${ }^{129}$ Batini et al. 2021.

${ }^{130}$ MIT Energy Initiative 2018; OECD/NEA 2012, 2019; International Energy Agency 2019; Zappa et al. 2019.

${ }^{131} \mathrm{https} / / / \mathrm{www}$. foratom.org/downloads/nuclear-energy-powering-the-economy-full-study/?wpd mdl=42758\&refresh=5f61d7fee0ce71600247806. Accessed 1 July 2021.
} 
nuclear industry generates an additional four euros in the European economy. ${ }^{132}$ Similarly, every dollar spent by an American nuclear power plant during the year will generate an additional four dollars for the local economy. ${ }^{133}$ As a result, nuclear energy investments provide not only a reliable and affordable source of electricity, but also considerable socioeconomic benefits, reinforcing the importance and benefit of placing nuclear power projects at the heart of any just energy transition policy.

\subsection{Conclusion}

The global coronavirus pandemic that is currently gripping the world has in many ways highlighted the considerable inequities that exist between, and within, different countries. It has also shown that when humanity comes together to resolve an emergency, it is possible to achieve monumental outcomes. The development of safe and effective COVID-19 vaccines in less than a year is a case in point, especially considering that the previous vaccine development record was more than four years. ${ }^{134}$ After decades of mostly rhetoric on climate change, the same sense of urgency must be used to take robust action to avoid the worst effects of climate change.

However, modern political discourse relating to the clean energy transition, and economic development more broadly, carries the characteristics of a 'zero-sum' mindset, positing that the populations of high income countries must accept lowering their standards of living to allow low and middle income countries to become more high powered, while limiting the level of developments these countries can expect. This is an anti-humanitarian philosophy that will undermine any serious efforts of achieving decarbonization, as well as merely entrenching already existing global inequalities. While it is conceivable that the world's wealthiest countries will undergo a major behavioural transformation and will consent to energy-restricted lifestyles, it is extremely unlikely that the same will apply to the world's low and middle income countries, which are home to more than $85 \%$ of the global population. ${ }^{135}$

These countries need more reliable, around-the-clock energy to ensure a higher standard of living for their populations, and it is within their right to strive for the same high powered lifestyles that high income countries have been enjoying for several generations. The key question at hand is whether these low and middle income countries will commit to the same high carbon, high pollution journey as others have in the past, or whether they will have access to the required skills, financing and technologies to leapfrog straight away to an energy system that is affordable, low carbon and reliable.

\footnotetext{
${ }^{132}$ Ibid.

${ }^{133}$ Nuclear Energy Institute 2012.

${ }^{134} \mathrm{https} / / / \mathrm{www}$.nationalgeographic.com/science/article/why-coronavirus-vaccine-could-takeway-longer-than-a-year. Accessed 1 July 2021.

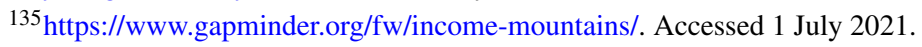


Nuclear technologies hold immense potential to fundamentally alter life prospects around the world, be it by providing abundant, sustainable and reliable electricity or combating hunger and diseases using various radioisotopes. Nuclear power provides a golden opportunity to embrace an abundance mindset once and for all, and it is the only technology that has a track record to prove not only that it can achieve deep decarbonization at the speed required, but also that it can help to bring vast quantities of electricity to populations across the world. Nuclear power has broken the correlation between economic growth and growing emissions, showing that it is possible to decarbonize the electricity systems of advanced economies within the timeframes necessary to avert the worst effects of climate change, whilst allowing high powered but sustainable lifestyles.

George Santayana's aphorism "those who cannot remember the past are condemned to repeat it" 136 offers some guidance relevant to the energy transition that humanity is embarking upon. It is clear that communities around the world have to wean themselves off their long standing addiction to fossil fuels, and that access to more electricity and a better quality of life will trump concerns about greenhouse gas emissions. With nuclear power, no such trade-off has to take place. A crucial first step towards this is for policymakers at all levels, be it local, national or international, to dare to challenge preconceived notions about nuclear technologies and stand for the opportunity they provide. Just as crucial is the leadership from the world's highincome countries- because of the legacy of past emissions, they have a responsibility to help low- and middle- income countries to leapfrog the fossil-powered development phase. This can be achieved by encouraging multilateral banks to support all low-carbon technologies, including nuclear, and promoting technical cooperation and knowledge transfer. If they do, the momentous task of building truly equitable, sustainable and aspirational societies around the world becomes considerably easier.

\section{References}

American Cancer Society (2014) The History of Cancer. https://www.cancer.org/content/dam/CRC/ PDF/Public/6055.00.pdf. Accessed 1 July 2021

American Cancer Society (2020) Lifetime Risk of Developing or Dying From Cancer. https://www. cancer.org/content/dam/CRC/PDF/Public/509.00.pdf. Accessed 1 July 2021

Arshi P S, Vahidi E, Zhao F (2018) Behind the Scenes of Clean Energy: The Environmental Footprint of Rare Earth Products. ACS Sustainable Chemistry \& Engineering 6:3311-3320

Avrin A-P, He G, Kammen D M (2015) Assessing the impacts of nuclear desalination and geoengineering to address China's water shortages. Desalination 360:1-7

Avrin A-P, He G, Kammen D M (2018) Chapter 7-Relevance of Nuclear Desalination as an Alternative to Water Transfer Geoengineering Projects: Example of China. In: Renewable Energy Powered Desalination Handbook. Butterworth-Heinemann, Oxford, pp 265-286

Baek J and Pride D (2014) On the income-nuclear energy-CO2 emissions nexus revisited. Energy Economics 43:6-10

${ }^{136}$ Santayana 1905. 
Batini N, Di Serio M, Fragetta M, Melina G, Waldron A (2021) Building Back Better: How Big Are Green Spending Multipliers? https://www.imf.org/-/media/Files/Publications/WP/2021/Eng lish/wpiea2021087-print-pdf.ashx. Accessed 1 July 2021

Belessiotis V, Papanicolaou E, Delyannis E (2010) Nuclear desalination: A review on past and present. Desalination and Water Treatment 20:45-50

Boretti A, Rosa L (2019) Reassessing the projections of the World Water Development Report. npj Clean Water 2

Bourguignon F, Morrisson C (2002) Inequality among World Citizens: 1820-1992. The American Economic Review 92:727-744

Bouyer J, Culbert N J, Dicko A H, Gomez Pacheco M, Virginio J, Pedrosa M C, Garziera L, Macedo Pinto A T, Klaptocz A, Germann J, Wallner T, Salvador-Herranz R, Argiles Herrero R, Yamada H, Balestrino F, Vreysen M J B (2020) Field performance of sterile male mosquitoes released from an uncrewed aerial vehicle. Science Robotics 5

BP (2020) BP Statistical Review of World Energy. https://www.bp.com/content/dam/bp/businesssites/en/global/corporate/pdfs/energy-economics/statistical-review/bp-stats-review-2020-fullreport.pdf. Accessed 1 July 2021

Brook B W (2012) Could nuclear fission energy, etc., solve the greenhouse problem? The affirmative case. Energy Policy 42:4-8

Candelise C, Saccone D, Vallino E (2021) An empirical assessment of the effects of electricity access on food security. World Development 141

Cao J, Cohen A, Hansen J, Lester R, Peterson P, Xu H (2016) China-U.S. cooperation to advance nuclear power. Science 353:547-548

Ceballos G and Ehrlich P R (2018) The misunderstood sixth mass extinction. Science 360:10801081

Ceballos G, Ehrlich P R, Barnosky A D, García A, Pringle R M, Palmer T M (2015) Accelerated modern human-induced species losses: Entering the sixth mass extinction. Science Advances DOI:https://doi.org/10.1126/sciadv.1400253

Ceballos G, Ehrlich P R, Dirzo R (2017) Biological annihilation via the ongoing sixth mass extinction signaled by vertebrate population losses and declines. Proceedings of the National Academy of Sciences of the United States of America 114:6089-6096

Chock R Y, Clucas B, Peterson E K, Blackwell B F, Blumstein D T, Church K, Fernández-Juricic E, Francescoli G, Greggor A L, Kemp P, Pinho G M, Sanzenbacher P M, Schulte B A, Toni P (2021) Evaluating potential effects of solar power facilities on wildlife from an animal behavior perspective. Conservation Science and Practice 3:319-328

Clack C T M, Qvist S A, Apt J, Bazilian M, Brandt A R, Caldeira K, David S J, Diakov V, Handschy M A, et al. (2017) Evaluation of a proposal for reliable low-cost grid power with $100 \%$ wind, water, and solar. Proceedings of the National Academy of Sciences 114:6722-6727

Cohen A J, Brauer M, Burnett R, Anderson H R, Frostad J, Estep K, Balakrishnan K, Brunekreef B,et al. (2017) Estimates and 25-year trends of the global burden of disease attributable to ambient air pollution: an analysis of data from the Global Burden of Diseases Study 2015. The Lancet 389 10082:1907-1918

Csik B J, Kupitz J (1997) Nuclear power applications: Supplying heat for homes and industries. IAEA Bulletin 39:21-25

Darre N C, Toor G S (2018) Desalination of Water: a Review. Current Pollution Reports 4:104-111

Deloitte (2019) Economic and Social Impact Report FORATOM. https://www.foratom.org/dow nloads/nuclear-energy-powering-the-economy-full-study/?wpdmdl=42758\&refresh $=5 \mathrm{f} 61 \mathrm{~d} 7 \mathrm{fee}$ 0ce71600247806. Accessed 1 July 2021

Department for Business, Energy, and Industrial Strategy (2021) BEIS Public Attitudes Tracker (March 2021, Wave 37, UK) https://assets.publishing.service.gov.uk/government/uploads/sys tem/uploads/attachment_data/file/985092/BEIS_PAT_W37_-_Key_Findings.pdf. Accessed 1 July 2021

Devanney J (2021) Why Nuclear Power has been a Flop. The CTX Press, Stevenson, WA 
Dinkelman T (2011) The Effects of Rural Electrification on Employment: New Evidence from South Africa. American Economic Review 101:3078-3108

Directorate-General for External Policies of the Union (European Parliament) (2018) Energy as a tool of foreign policy of authoritarian states, in particular Russia. https://op.europa.eu/en/pub lication-detail/-/publication/1c80b8c6-58b6-11e8-ab41-01aa75ed71a1/language-en. Accessed 1 July 2021

Dirzo R, Young H S, Galetti M, Caballos G, Isaac N J B, Collen B (2014) Defaunation in the Anthropocene. Science 345:401-406

Ember (2020) Global Electricity Review. Ember, London https://ember-climate.org/wp-content/upl oads/2020/03/Ember-2020GlobalElectricityReview-Web.pdf. Accessed 1 July 2021

Enkerlin W R (2005) Impact of Fruit Fly Control Programmes Using the Sterile Insect Technique. In: Dyck V A, Hendrichs J, Robinson A (eds) Sterile Insect Technique, Springer, Dordrecht, pp 651-676

Food and Agriculture Organization (FAO) (2017) The future of food and agriculture: Trends and challenges. http://www.fao.org/3/i6583e/i6583e.pdf. Accessed 1 July 2021

Food and Agriculture Organization (FAO), International Fund for Agricultural Development, UNICEF, World Food Programme (WFP), World Health Organization (WHO) (2021) The State of Food Security and Nutrition in the World 2021 - Transforming food systems for food security, improved nutrition and affordable healthy diets for all. https://www-pub.iaea.org/MTCD/Public ations/PDF/TE-1760_web.pdf. Accessed 1 July 2021

Goyal R, Marsh K, McKee N, Welch M (2021) Opposition to Renewable Energy Facilities in the United States. https://climate.law.columbia.edu/sites/default/files/content/RELDI\%20r eport\%20updated\%209.10.21.pdf. Accessed 1 July 2021

Gross S (2020) Renewables, Land Use, and Local Opposition. https://www.brookings.edu/ wp-content/uploads/2020/01/FP_20200113_renewables_land_use_local_opposition_gross.pdf. Accessed 1 July 2021

Habib K, Hamelin L, Wenzel H (2016) A dynamic perspective of the geopolitical supply risk of metals. Journal of Cleaner Production 133:850-858

Heard B, Brook B, Wigley T, Bradshaw C (2017) Burden of proof: A comprehensive review of the feasibility of $100 \%$ renewable-electricity systems. Renewable and Sustainable Energy Reviews 76:1122-1133

Higgs S (2018) It Is Official: Vector-Borne and Zoonotic Diseases in the United States and Territories on the Rise-Now What? Vector-Borne and Zoonotic Diseases 18:285

Hong S, Bradshaw C J A, Brook B W (2015) Global zero-carbon energy pathways using viable mixes of nuclear and renewables. Applied Energy 143:451-459

Ingersoll D, Houghton Z, Bromm R, Desportes C (2014a) NuScale small modular reactor for Co-generation of electricity and water. Desalination 340:84-93

Ingersoll D, Houghton Z, Bromm R, Desportes C (2014b) Integration of NuScale SMR With Desalination Technologies. In: Proceedings of the ASME 2014 Small Modular Reactors Symposium. ASME 2014 Small Modular Reactors Symposium, Washington, DC

Ingersoll E, Gogan K (2020) Missing Link to a Livable Climate: How Hydrogen-Enabled Synthetic Fuels Can Help Deliver the Paris Goals. LucidCatalyst, London \& Cambridge, MA

Intergovernmental Science-Policy Platform on Biodiversity and Ecosystem Services (2019) Summary for policymakers_Global Assessment. http://ipbes.net/sites/default/files/2020-02/ ipbes_global_assessment_report_summary_for_policymakers_en.pdf. Accessed 1 July 2021

International Agency for Research on Cancer (2020) World Cancer Report: Cancer research for cancer prevention. Wild C P, Weiderpass E, Stewart B W (eds). https://shop.iarc.fr/products/ world-cancer-report-cancer-research-for-cancer-prevention-pdf. Accessed 1 July 2021

International Atomic Energy Agency (IAEA) (2015) Use of Radiotracers to Study Surface Water Processes. IAEA, Vienna

International Atomic Energy Agency (IAEA) (2018) Climate Change and Nuclear Power 2018. IAEA, Vienna 
International Atomic Energy Agency (IAEA) (2020) Nuclear technology review. https://www.iaea. org/sites/default/files/gc/gc64-inf2.pdf. Accessed 1 July 2021

International Energy Agency (2019) Nuclear Power in a Clean Energy System. https://www.iea. org/reports/nuclear-power-in-a-clean-energy-system. Accessed 1 July 2021

International Energy Agency (2020) Coal 2020 Analysis and forecast to 2025. https://iea.blob.core. windows.net/assets/00abf3d2-4599-4353-977c-8f80e9085420/Coal_2020.pdf. Accessed 1 July 2021

International Energy Agency (2021) Electricity Market Report. https://www.iea.org/reports/electr icity-market-report-july-2021. Accessed 1 July 2021

International Energy Agency (2021) Net Zero by 2050: A Roadmap for the Global Energy Sector. https://www.iea.org/reports/net-zero-by-2050. Accessed 1 July 2021

International Energy Agency (2021) The Role of Critical Minerals in Clean Energy Transitions, IEA: Paris. World Nuclear Association (2021). Mineral Requirements for Electricity Generation. Accessed here: https://world-nuclear.org/information-library/energy-and-the-environment/ mineral-requirements-for-electricity-generation.aspx. Accessed 30 November 2021

International Renewable Energy Agency, International Energy Agency Photovoltaic Power Systems (2016) End-of-life management: solar photovoltaic panels. https://www.irena.org/-/media/Files/ IRENA/Agency/Publication/2016/IRENA_IEAPVPS_End-of-Life_Solar_PV_Panels_2016. pdf. Accessed 1 July 2021

Intergovernmental Panel on Climate Change (IPCC) (2018) Summary for Policymakers. In: MassonDelmotte V, Zhai P, Pörtner H, Roberts D, Skea J, Shukla P, Pirani A, Moufouma-Okia W, Péan C, Pidcock R, Connors S, Matthews J, Chen Y, Zhou X, Gomis M, Lonnoy E, Maycock T, Tignor $\mathrm{M}$, Waterfield T (eds), Global Warming of $1.5^{\circ} \mathrm{C}$. An IPCC Special Report on the impacts of global warming of $1.5^{\circ} \mathrm{C}$ above pre-industrial levels and related global greenhouse gas emission pathways. https://www.ipcc.ch/site/assets/uploads/sites/2/2019/05/SR15_SPM_version_report_ LR.pdf. Accessed 1 July 2021

IPPC Secretariat (2021) Scientific review of the impact of climate change on plant pests - A global challenge to prevent and mitigate plant pest risks in agriculture, forestry and ecosystems. FAO on behalf of the IPPC Secretariat, Rome

Jaffray D A, Gospodarowicz M K (2015) Radiation Therapy for Cancer. In: H. Gelband H, Jha P, Sankaranarayanan R, Horton S (eds) Cancer: Disease Control Priorities, 3rd edn, Vol. 3. The International Bank for Reconstruction and Development/The World Bank, Washington DC

Jarvis S, Deschenes O, Jha A (2019) The Private and External Costs of Germany's Nuclear Phase-Out (Working Paper 26598). National Bureau of Economic Research, Cambridge, MA

Jasserand F, Devezeaux de Lavergne J-G (2016) Initial economic appraisal of nuclear district heating in France. EPJ Nuclear Sciences \& Technologies 2

Jiang Y (2009) China's water scarcity. Journal of Environmental Management 90:3185-3196

Jiménez Cisneros B E, Oki T, Arnell N W, Benito G, Cogley J G, Doll P, Jiang T, Mwakalila S S (2014) Freshwater resources. In: Climate Change 2014: Impacts, Adaptation, and Vulnerability. Part A: Global and Sectoral Aspects. Contribution of Working Group II to the Fifth Assessment Report of the Intergovernmental Panel on Climate Change. Cambridge University Press, Cambridge, pp 229-269

Jones E, Qadir M, van Vliet M T, Smakhtin V, Kang S-M (2019) The state of desalination and brine production: A global outlook. Science of the Total Environment 657:1343-1356

Karekezi S, McDade S, Boardman B, Kimani J, Lustig N (2012) Energy, Poverty, and Development. In: Global Energy Assessment: Toward a Sustainable Future. Cambridge University Press, Cambridge, pp 151-190

Khandker S R, Samad H A, Ali R, Barnes D F (2014) Who Benefits Most from Rural Electrification? Evidence in India. The Energy Journal 35:75-96

Kharecha P A, Hansen J E (2013) Prevented Mortality and Greenhouse Gas Emissions from Historical and Projected Nuclear Power. Environmental Science and Technology 47:4889-4895

Klassen W (2009) Introduction: development of the sterile insect technique for African malaria vectors. Malaria Journal 8 
Klassen W, Curtis C F, Hendrichs J (2021) History of the Sterile Insect Technique. In: Dyck V A, Hendrichs J, Robinson A S (eds) Sterile Insect Technique: Principles and Practice in Area-Wide Integrated Pest Management, 2nd edn. Boca Raton, FL, pp 1-44

Klassen W, Vreysen M J B (2021) Area-Wide Integrated Pest Management and the Sterile Insect Technique. In: Dyck V A, Hendrichs J, Robinson A S (eds) Sterile Insect Technique. CRC Press, Boca Raton, pp 75-112

Lee J C K, Wen Z (2017) Rare Earths from Mines to Metals: Comparing Environmental Impacts from China's Main Production Pathways. Journal of Industrial Ecology 21:1277-1290

Liddle B, Sadorsky P (2017) How much does increasing non-fossil fuels in electricity generation reduce carbon dioxide emissions? Applied Energy 197:212-221

Lindberg J C H (2017) Sweden's silent phaseout. Nuclear Engineering International 62:12-14

Lindberg J C H (in press) Building an atomic future: The role for nuclear power in addressing major humanitarian challenges in the 21st century. Journal of Nuclear Engineering and Radiation Science

Mark H E, Dias da Costa G, Pagliari C, Unger S A (2020) Malnutrition: the silent pandemic. BMJ 371

Mekonnen M M, Hoekstra A Y (2016) Four billion people facing severe water scarcity. Science Advances 2

MIT Energy Initiative (2018) The Future of Nuclear Energy in a Carbon-constrained World: An Interdisciplinary MIT Study. https://energy.mit.edu/research/future-nuclear-energy-carbon-con strained-world/. Accessed 1 July 2021

Niu S, Jia Y, Wang W, He R, Hu L, Liu Y (2013) Electricity consumption and human development level: A comparative analysis based on panel data for 50 countries. International Journal of Electrical Power \& Energy Systems 53:338-347

Nuclear Energy Institute (2012) Nuclear Energy's Economic Benefits - Current and Future. http:// large.stanford.edu/courses/2018/ph241/may2/docs/nei-apr12.pdf. Accessed 1 July 2021

O'Neil S G (2021) Community obstacles to large scale solar: NIMBY and renewables. Journal of Environmental Studies and Sciences 11:85-92

Organisation for Economic Co-operation and Development/Nuclear Energy Agency (OECD/NEA) (2012) The Role of Nuclear Energy in a Low-carbon Energy Future. https://www.oecdnea.org/jcms/pl_14562/the-role-of-nuclear-energy-in-a-low-carbon-energy-future?details=true. Accessed 1 July 2021

Organisation for Economic Co-operation and Development/Nuclear Energy Agency (OECD/NEA) (2019) The Costs of Decarbonisation: System Costs with High Shares of Nuclear and Renewables. https://www.oecd-nea.org/jcms/pl_15000/the-costs-of-decarbonisation-system-costswith-high-shares-of-nuclear-and-renewables. Accessed 1 July 2021

Qvist S A, Brook B W (2015) Potential for Worldwide Displacement of Fossil-Fuel Electricity by Nuclear Energy in Three Decades Based on Extrapolation of Regional Deployment Data. PLoS ONE 10

Qvist S, Gladysz P, Bartela L, Sowizczal A (2021) Retrofit Decarbonization of Coal Power PlantsA Case Study for Poland. Energies 14

Rao N D, Pachauri S (2017) Energy access and living standards: some observations on recent trends. Environmental Research Letters 12

Rockström J, Steffen W, Noone K, et al. (2009) A safe operating space for humanity. Nature 461:472-475

Rogelj J, Shindell D, Jiang K, Fifita S, Forster P, Ginzburg V, Handa C, Kheshgi H, Kobayashi S, Kriegler E, Mundaca L, Séférian R, Vilariño M V (2018) Mitigation Pathways Compatible with $1.5^{\circ} \mathrm{C}$ in the Context of Sustainable Development. In: Masson-Delmotte V, Zhai P, Pörtner H, Roberts D, Skea J, Shukla P, Pirani A, Moufouma-Okia W, Péan C, Pidcock R, Connors S, Matthews J, Chen Y, Zhou X, Gomis M, Lonnoy E, Maycock T, Tignor M, Waterfield T (eds), Global Warming of $1.5^{\circ} \mathrm{C}$. An IPCC Special Report on the impacts of global warming of $1.5^{\circ} \mathrm{C}$ above pre-industrial levels and related global greenhouse gas emission pathways. World Metorological Organisation, Geneva, pp 93-174 
Rosling H, Rosling O, Rosling Rönnlund A (2018) Factfulness. Sceptre, London

Royal Society (2020) Nuclear cogeneration: civil nuclear energy in a low-carbon future policy briefing. https://royalsociety.org/topics-policy/projects/low-carbon-energy-programme/nuclearcogeneration/. Accessed 1 July 2021

Santayana G (1905) The Life of Reason; or the Phases of Human Progress. Charles Scribner's Sons, New York

Schlömer S, Bruckner T, Fulton L, Hertwich E, McKinnon A, Perczyk D, Roy J, Schaeffer R, Sims R, Smith P, Wiser R (2014) Annex III: Technology-specific cost and performance parameters. In: Edenhofer O, Pichs-Madruga R, Sokona Y, Farahani E, Kadner S, Seyboth K, Adler A, Baum I, Brunner S, Eickemeier P, Kriemann B, Savolainen J, Schlömer S, von Stechow C, Zwickel T, Minx J (eds) Climate Change 2014: Mitigation of Climate Contribution of Working Group III to the Fifth Assessment Report of the Intergovernmental Panel on Climate Change. Cambridge University Press, Cambridge and New York, pp 1329-1356

Schmeller D S, Courchamp F, Killeen G (2020) Biodiversity loss, emerging pathogens and human health risks. Biodiversity and Conservation 29:3095-3102

Smittenaar C R, Petersen K A, Stewart K, Moitt N (2016) Cancer incidence and mortality projections in the UK until 2035. British Journal of Cancer 115:1147-1155

Steffen W, Richardson K, Rockström J, Cornell S E, Fetzer I, Bennett E M, Biggs R, Carpenter S R, de Vries W, de Wit C A, Folke C, Gerten D, Heinke J, Mace G M, et al. (2015) Planetary boundaries: Guiding human development on a changing planet. Science 347

Stegen K S (2015) Heavy rare earths, permanent magnets, and renewable energies: An imminent crisis. Energy Policy 79:1-8

Stevens L (2017) The Footprint of Energy: Land Use of U.S. Electricity Production. https://docs. wind-watch.org/US-footprints-Strata-2017.pdf. Accessed 1 July 2021

Tanner A M, Johnston A L (2017) The Impact of Rural Electric Access on Deforestation Rates. World Development 94:174-185

Thayer D W (1993) Extending Shelf Life of Poultry and Red Meat by Irradiation Processing. Journal of Food Protection 56:831-833

Tscharntke T, Clough Y, Wanger T C, Jackson L, Motzke I, Perfecto I, Vandermeer J, Whitbread A (2012) Global food security, biodiversity conservation and the future of agricultural intensification. Biological Conservation 151:53-59

Tyson A, Kennedy B, Funk C (2021) Gen Z, Millennials Stand Out for Climate Change Activism, Social Media Engagement With Issue. https://www.pewresearch.org/science/wp-content/upl oads/sites/16/2021/05/PS_2021.05.26_climate-and-generations_REPORT.pdf. Accessed 1 July 2021

United Nations Environment Programme (UNEP) (2020) Responsible consumption. https:// wedocs.unep.org/bitstream/handle/20.500.11822/22747/12_Responsible\%20consumption\% 20and\%20production_FINAL.pdf?sequence=1\&isAllowed=y. Accessed 12 June 2021

UNICEF (2021) Reimagining WASH-Water security for all. United Nations Children's Fund (UNICEF), New York. https://www.unicef.org/media/95241/file/water-security-for-all.pdf. Accessed 1 July 2021

United Nations (UN) (2021) Progress towards the Sustainable Development Goals. E/2021/58. https://digitallibrary.un.org/record/3930067?ln=en. Accessed 1 July 2021

United Nations Economic Commission for Europe (UNECE) (2021) Use of Nuclear Fuel Resources for Sustainable Development - Entry Pathways. https://unece.org/sites/default/files/2021-03/ UNECE\%20Use\%20of\%20nuclear\%20fuel\%20resources\%20for\%20sustainable\%20develop ment_\%20Final_0.pdf. Accessed 1 July 2021

United Nations Water (UN-Water) (2021) Summary Progress Update 2021: SDG 6-water and sanitation for all. https://www.unwater.org/publications/summary-progress-update-2021-sdg-6water-and-sanitation-for-all/. Accessed 1 July 2021

Van Gosen B S, Verplanck P L, Seal II R R, Long K R, Gambogi J (2017) Rare-earth elements. In: Schulz K J, DeYoung Jr J H, Seal II R R, Bradley D C (eds) Critical Mineral Resources of the 
United States - Economic and Environmental Geology and Prospects for Future Supply, U.S. Geological Survey Professional Paper 1802, Reston, pp 539-571

Värri K, Syri S (2019) The Possible Role of Modular Nuclear Reactors in District Heating: Case Helsinki Region. Energies 12

Verma J, Gautam S (2015) Food irradiation and its role in shelf life extension of horticulture produce: a comprehensive evaluation of studies carried out in India and abroad. In: Proceedings of the DAE-BRNS life sciences symposium on advances in microbiology of food, agriculture, health and environment. Bio-Science Group, Bhabha Atomic Research Centre, Mumbai

Vohra K, Vodonos A, Schwartz J, Marais E A, Sulprizio M P, Mickley L J (2021) Global mortality from outdoor fine particle pollution generated by fossil fuel combustion: Results from GEOSChem. Environmental Research 195

Willcox M, Waters L, Wanjiru H, Pueyo A, Hanna R, Palit D, Sharma K R (2015) Utilising Electricity Access for Poverty Reduction. https://assets.publishing.service.gov.uk/media/57a08975e527 4a27b20000b5/61290-Electricity_Access_for_Poverty_Reduction_MainReport.pdf. Accessed 1 July 2021

Winther T, Matinga M N, K. Ulsrud K, Standal K (2017) Women's empowerment through electricity access: scoping study and proposal for a framework of analysis. Journal of Development Effectiveness 9:389-417

World Health Organization (WHO), International Atomic Energy Agency (IAEA) (2020) Guidance Framework for Testing the Sterile Insect Technique as a Vector Control Tool against AedesBorne Diseases. https://apps.who.int/iris/bitstream/handle/10665/331679/9789240002371-eng. pdf?ua=1. Accessed 1 July 2021

World Health Organization (WHO) (1994) Safety and nutritional adequacy of irradiated food. https://apps.who.int/iris/bitstream/handle/10665/39463/9241561629-eng.pdf?seq uence $=4 \&$ is Allowed $=y$. Accessed 1 July 2021

World Health Organization (WHO) (2018) Latest global cancer data: Cancer burden rises to 18.1 million new cases and 9.6 million cancer deaths in 2018. https://www.who.int/cancer/PRGlob ocanFinal.pdf. Accessed 1 July 2021

World Health Organization (WHO), Food and Agriculture Organization (FAO) (1988) Food irradiation: A technique for preserving and improving the safety of food. https://apps.who.int/iris/bit stream/handle/10665/38544/9241542403_eng.pdf?sequence=1\&isAllowed=y. Accessed 1 July 2021

World Nuclear Association (2019) The Silent Giant: The need for nuclear in a clean energy system. https://www.world-nuclear.org/getattachment/Our-Association/Publications/Pos ition-statements/the-silent-giant/the-silent-giant.pdf.aspx. Accessed 1 July 2021

World Nuclear Association (2020) World Nuclear Performance Report 2020. https://www.worldnuclear.org/getmedia/3418bf4a-5891-4ba1-b6c2-d83d8907264d/performance-report-2020-v1. pdf.aspx. Accessed 1 July 2021

World Nuclear Association (2021) The Role of Critical Minerals in Clean Energy Transitions, IEA: Paris. World Nuclear Association (2021). Mineral Requirements for Electricity Generation. Accessed here: https://worldnuclear.org/information-library/energy-and-the-environment/ mineral-requirements-for-electricity-generation.aspx. Accessed 30 November 2021

WWF (2020) Living Planet Report 2020 - Bending the curve of biodiversity loss. https://f.hubspo tusercontent20.net/hubfs/4783129/LPR/PDFs/ENGLISH-FULL.pdf. Accessed 1 July 2021

Zappa W, Junginger M, van den Broek M (2019) Is a 100\% renewable European power system feasible by 2050? Applied Energy 233-234:1027-1050

Ziegler L, Gonzalez E, Rubert T, Smolka U, Melero J J (2018) Lifetime extension of onshore wind turbines: A review covering Germany, Spain, Denmark, and the UK. Renewable and Sustainable Energy Reviews 82:1261-1271

Ziolkowska J R (2015) Is Desalination Affordable?-Regional Cost and Price Analysis. Water Resources Management 29:1385-1397 
The opinions expressed in this publication are those of the authors/editors and do not necessarily reflect the views of the IAEA: International Atomic Energy Agency, its Board of Directors, or the countries they represent.

Open Access This book is licensed under the terms of the Creative Commons Attribution 3.0 IGO license (http://creativecommons.org/licenses/by/3.0/igo/), which permits use, sharing, adaptation, distribution and reproduction in any medium or format, as long as you give appropriate credit to the IAEA: International Atomic Energy Agency, provide a link to the Creative Commons license and indicate if changes were made.

Any dispute related to the use of the works of the IAEA: International Atomic Energy Agency that cannot be settled amicably shall be submitted to arbitration pursuant to the UNCITRAL rules. The use of the IAEA: International Atomic Energy Agency's name for any purpose other than for attribution, and the use of the IAEA: International Atomic Energy Agency's logo, shall be subject to a separate written license agreement between the IAEA: International Atomic Energy Agency and the user and is not authorized as part of this CC-IGO license. Note that the link provided above includes additional terms and conditions of the license.

The images or other third party material in this book are included in the book's Creative Commons license, unless indicated otherwise in a credit line to the material. If material is not included in the book's Creative Commons license and your intended use is not permitted by statutory regulation or exceeds the permitted use, you will need to obtain permission directly from the copyright holder. 